\begin{tabular}{|c|c|c|}
\hline 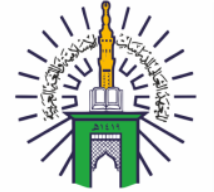 & 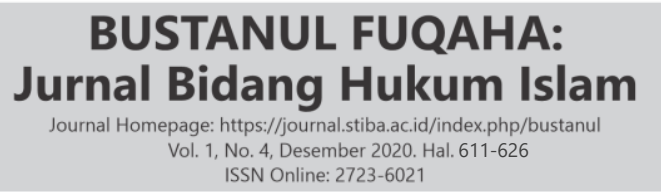 & $\begin{array}{l}\text { Jumal } \\
\text { BUSTANUL } \\
\text { FUQAHA } \\
\text { jumal Eididng thutum slam }\end{array}$ \\
\hline
\end{tabular}

\title{
ADAT MAPPASIKARAWA PADA PERKAWINAN MASYARAKAT BUGIS PERSPEKTIF HUKUM ISLAM (STUDI KASUS DESA KABALLANGAN KABUPATEN PINRANG)
}

\author{
Syandri \\ Sekolah Tinggi Ilmu Islam dan Bahasa Arab (STIBA) Makassar \\ Email: syandri@stiba.ac.id \\ Kasman Bakry \\ Sekolah Tinggi Ilmu Islam dan Bahasa Arab (STIBA) Makassar \\ Email: kasmanbakry@stiba.ac.id \\ Salman Al Farisi \\ Sekolah Tinggi Ilmu Islam dan Bahasa Arab (STIBA) Makassar \\ Email: salmanalfarisi5862@gmail.com
}

\section{Keywords : \\ Culture, Mappasikarawa Marriage, Islamic Law, Pinrang} ABSTRACT

This study aimed to determine the tradition Mappasikarawa in the marriage of the Bugis community from the perspective of Islamic law. The problems studied in this research are; First, how is the marriage tradition of the Bugis community, Second, what is the view of Islamic law on the Mappasikarawa tradition in Kaballangan Village, Duampanua District, Pinrang Regency, South Sulawesi. To find the answers to the above problems, the writer used the qualitative method (field research) by using normative, historical, and sociological approaches. The results of the research found are as follows: First, the Mappasikarawa tradition in the marriage of the Bugis Pinrang community is one of the activities performed before the marriage contract with the aim that the bride and groom get happiness, peace, prosperity, physically and spiritually in their life. Second, in the view of Islamic law, the Mappasikarawa tradition is not permissible in reference to a process that violates the rules of Islamic law in its implementation where the bride and the groom in direct contact before being a legal partner since Mappasikarawa is performed before the marriage contract. It means that there is an illegal interaction between two people who are not yet included in

Kata kunci :

Adat, Mappasikarawa, Perkawinan, Hukum Islam, Pinrang

\section{the mahram category \\ the mahram category}

Penelitian ini bertujuan untuk mengetahui hukum Tradisi Mappasikarawa pada perkawinan masyarakat Bugis dalam perspektif hukum Islam. Permasalahan yang dikaji dalam penelitian ini yaitu: Pertama, bagaimana tradisi perkawinan suku Bugis; Kedua, bagaimana pandangan hukum Islam terhadap tradisi mappasikarawa di Desa Kaballangan Kecamatan Duampanua Kabupaten Pinrang Sulawesi Selatan. Untuk mendapatkan jawaban atas permasalahan tersebut, maka digunakan jenis penelitian lapangan (field research) kualitatif dengan menggunakaan metode pendekatan normatif, historis dan sosiologis. Hasil penelitian yang ditemukan adalah sebagai berikut: Pertama, tradisi Mappasikarawa 


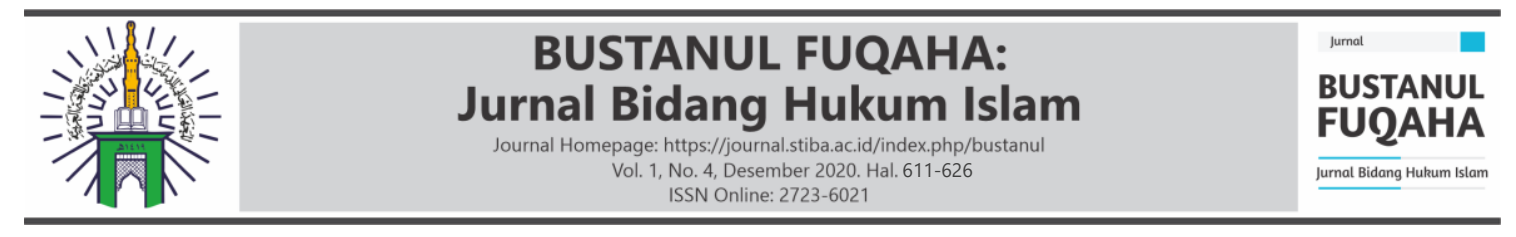

\begin{abstract}
pada perkawinan suku Bugis Pinrang ialah salah satu kegiatan yang dilakukan sebelum akad nikah dengan tujuan agar kedua mempelai pengantin mendapatkan kebahagiaan, kedamaian, kesejahteraan, lahir dan batin dalam mengarungi bahtera kehidupan rumah tangga. Kedua, dalam tinjauan hukum Islam tradisi mappasikarawa ini tidak disyariatkan melihat adanya proses yang melanggar aturan syariat Islam dalam pelaksanaannya yaitu adanya persentuhan dan interaksi langsung kedua mempelai sebelum sah menjadi suami istri, karena Mappasikarawa dilakukan sebelum akad nikah, itu berarti adanya interaksi tidak halal antar dua orang yang belum masuk kategori mahram.
\end{abstract}

\title{
PENDAHULUAN
}

Salah satu kekayaan yang dimiliki bangsa Indonesia adalah keanekaragaman suku di dalamnya yang menyebabkan keanekargaman dalam adat istiadat dan budaya masing-masing dari suku-suku tersebut. Jika melihat keanekaragaman budaya yang ada tentu saja ini merupakan salah satu nikmat Allah swt. untuk bangsa ini, karena keanekaragaman yang ada merupakan suatu hikmah dan tujuan yang sangat mulia yaitu agar manusia bisa saling mengenal satu dengan yang lainnya sebagaimana firman Allah swt. dalam Qs. al-Ḥujurāt/49:13,

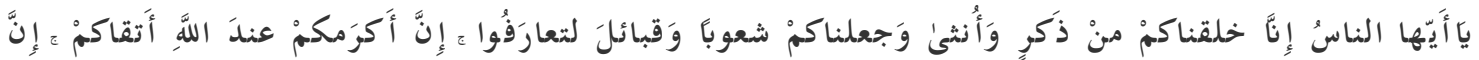

$$
\begin{aligned}
& \text { اللَّ عَليمهُ خبيرُ }
\end{aligned}
$$

Terjemahnya:

“Wahai manusia! Sungguh, kami telah menciptakan kamu dari seorang laki-laki dan seorang perempuan, kemudian kami jadikan kamu berbangsa-bangsa dan bersuku-suku agar kamu saling mengenal. Sungguh, yang paling mulia di antara kamu di sisi Allah ialah orang yang paling bertakwa. Sungguh, Allah Maha Mengetahui, Maha Teliti"'.

Selain itu, kita diperintahkan untuk mensyukuri dan menghargai nikmat yang besar ini, kita sebagai manusia juga diperintahkan untuk memakmurkan dan mengatur setiap urusan antar sesama manusia dengan baik, karena demikianlah tugas manusia di muka bumi yaitu menjadi khalifah atau pemimpin yang memakmurkannya dengan kebaikan. Oleh sebab itu, kehidupan berislam yang baik pada suatu masyarakat ${ }^{2}$ dapat berimplikasi pada keamanan, ketentraman dan kemakmuran serta keberkahan hidup manusia. Demikian pula bila manusia melaksanakan tugasnya dengan baik sebagai khā İ fah fi al-arḍ, sebagaimana Allah swt. Berfirman dalam Qs. al-Baqarah/2:30,

${ }^{1}$ Kementrian Agama Republik Indonesia, Alquran al-Karim dan Terjemahnya, (Cet II; Yogyakarta: Ma'had al-Nabawī, 2011 M), h. 517.

${ }^{2}$ Usman, M. H., \& Aswar, A., "KORELASI KEHIDUPAN BERISLAM MASYARAKAT DESA BARUGA DENGAN KEMAKMURAN, KEAMANAN DAN KETENTRAMAN HIDUP", Al-Din: Jurnal Dakwah dan Sosial Keagamaan 6, no. 1 (2020). 


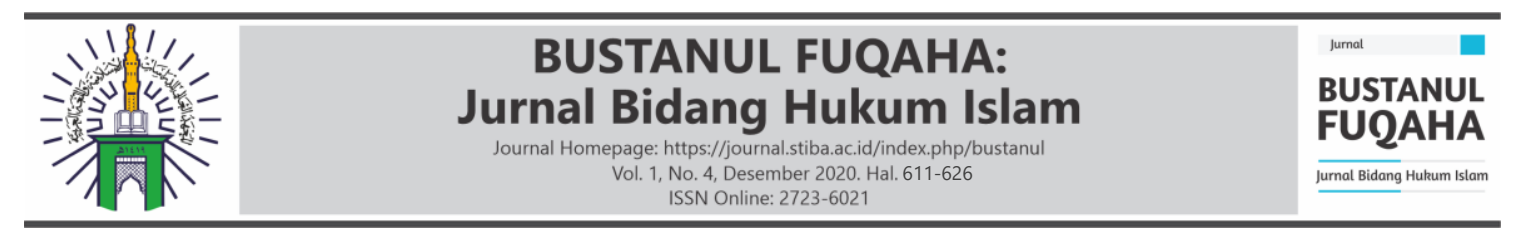

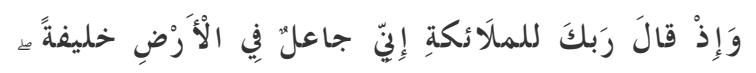

Terjemahnya:

"Ingatlah ketika tuhanmu berfirman kepada para Malaikat: sesungguhnya aku hendak menjadikan seorang khalifah di muka bumi"3.

Perintah mengatur dan memakmurkan bumi ini tentu saja meliputi seluruh aspek kehidupan di dalamnya. Baik itu aspek sosial, budaya, ekonomi, politik, dan lainnya, sehingga diharapkan kehidupan makhluk yang berdiam di atasnya terutama manusia bisa sampai pada satu titik kebahagiaan yang diharapkan menyeluruh dan adil ${ }^{4}$. Konsep keadilan itu sendiri, pada aplikasinya, menghendaki manusia agar senantiasa terhindar dari dosa dan senantiasa terjaga dalam keimanannya ${ }^{5}$. Sementara itu, salah satu bagian dari aspek budaya (peri kehidupan) manusia yang sangat penting adalah perkawinan. Untuk itu, konsep keadilan tetap harus dijalankan dengan mengacu pada timbangan syariat.

Beragamnya suku bangsa di dunia ini dan terkhusus di Indonesia juga melahirkan keberagaman pula dalam tradisi dan budaya perkawinan. Islam sebagai agama yang paripurna, yang Allah swt. turunkan sebagai petunjuk bagi manusia agar meraka memiliki pedoman dalam bermuamalah dan berinteraksi sesama mereka agar setiap dari manusia bisa sampai pada tujuan hidup yang bahagia tanpa ada pihak yang dirugikan atau dizalimi. Salah satu yang menjadi pokok perhatian agama Islam bahkan memiliki porsi yang sangat besar adalah perkawinan. Hal ini dikarenakan dalam Islam perkawinan merupakan salah satu ibadah yang sangat mulia dan prosesi yang sangat sakral sehingga dalam pelaksanaannya, Islam mengatur dengan sangat ketat dan terperinci.

Hal ini juga dikarenakan Islam ingin mengantarkan setiap manusia sampai pada tujuan mulia dari perkawinan itu sendiri. Kemudian di samping keindahan akan keanekaragaman dan perbedaan budaya antar suku di Indonesia, tentu saja juga tak bisa lepas dari kekurangan-kekurangan dan kekeliruan-kekeliruan yang ada, baik itu dari segi keyakinan maupun praktik kehidupannya. Di mana hal ini ada yang telah berlangsung sekian abad lamanya, ada pula yang belum lama mengalami perubahan yang diakibatkan pergantian generasi yang tidak diiringi dengan warisan ilmu yang cukup.

Pada saat mendapati apa yang selama ini menjadi keyakinan maupun praktek keseharian yang ternyata tidak mengarah pada tujuan kehidupan yang luhur dan bahagia di mana hal ini telah berlangsung turun temurun dari nenek moyang, maka bukanlah suatu hal yang bijak jika hal tersebut didiamkan dan tidak menaruh perhatian di dalamnya, meskipun tentu saja niat untuk meluruskan dan memperbaiki suatu kekeliruan

\footnotetext{
${ }^{3}$ Kementrian Agama Republik Indonesia, Alquran al-Karim dan Terjemahnya, h. 6.

${ }^{4}$ Abū Mālik Kamāl Ibn Sayyid Sālim, Șạịh Fiqh al-Sunnah, Juz 1 (Cet I; Miṣr: Maktabah alTaufïkiyah, 2003), h. 53.

${ }^{5}$ Rahman, R. A., “Konsep Keadilan dalam Alquran”, NUKHBATUL'ULUM: Jurnal Bidang Kajian Islam 2, no. 1 (2016): h. 174.
} 


\begin{tabular}{|c|c|c|}
\hline 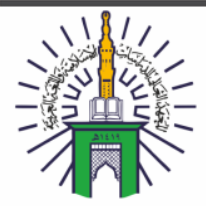 & 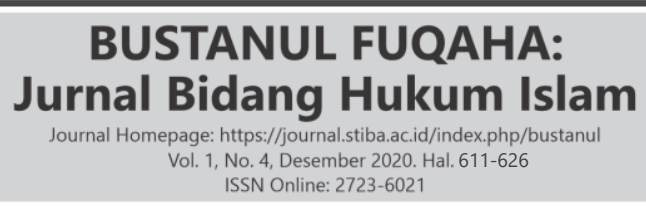 & $\begin{array}{l}\text { jumal } \\
\text { BUSTANUL } \\
\text { FUQAHA } \\
\text { jumal Bidang tuluum slam }\end{array}$ \\
\hline
\end{tabular}

yang telah berlangsung sekian lama bahkan telah mendarah daging diakui sebagai sesuatu yang tidak mudah dihilangkan. Namun, di sinilah sebenarnya letak tantangan bagi yang mau berpikir dan mengambil pelajaran akan kehidupan dan generasi manusia yang telah lewat.

Salah satu suku besar yang ada di Indonesia adalah suku Bugis. Suku yang telah ada berabad-abad lamanya ini memiliki nilai budaya dan adat istiadat yang sangat banyak. Selain itu, orang-orang suku Bugis juga terkenal memiliki pegangan dan kebanggaan yang sangat besar pada tradisinya, sehingga keberadaan suku ini masih tetap eksis hingga hari ini dengan corak sukunya yang khas, baik yang masih asli maupun yang telah tercampur pengaruh luar atau bahkan sedikit bergeser dari apa yang diwariskan oleh nenek moyang meraka ${ }^{6}$.

Masyarakat suku Bugis terkenal dengan adat istiadat dan tradisi yang kental. Tradisi secara garis besar adalah adat atau kebiasaan turun-temurun dari nenek moyang yang masih dijalankan dalam masyarakat dan penilaian atau anggapan bahwa cara-cara yang telah ada merupakan yang paling baik dan benar ${ }^{7}$. Seiring dengan perkembangan zaman, sentuhan teknologi modern telah mempengaruhi dan menyentuh masyarakat suku Bugis, namun kebiasaan-kebiasaan yang merupakan tradisi turun temurun bahkan telah menjadi adat masih sukar untuk dihilangkan. Kebiasaan-kebiasaan tersebut masih sering dilakukan, meskipun dalam pelaksanaannya telah mengalami perubahan, namun nilai-nilai dan makna masih tetap terpelihara dalam setiap upacara tersebut. Ada dua tahap dalam proses pelaksanaan perkawinan masyarakat Bugis yaitu tahap sebelum dan sesudah akad perkawinan. Bagi masyarakat Sulawesi Selatan pada umumnya, masyarakat Bugis khususnya menganggap bahwa upacara perkawinan adalah suatu hal yang sangat sakral, artinya mengandung nilai-nilai yang suci ${ }^{8}$.

Suku Bugis terkenal dengan adat istiadatnya yang kental seperti di daerah Pinrang. Masyarakat suku Bugis di Kabupaten Pinrang masih menjunjung tinggi tradisi dan adat istiadat yang dipakai dari dahulu hingga sekarang dan sudah diterapkan pada masyarakat setempat. Seperti halnya di Desa Kaballangan Kecamatan Duampanua Kabupaten Pinrang, di mana terdapat suatu adat dan kebiasaan yang masih dipertahankan yang dikenal dengan tradisi "Mappasikarawa”. Mappasikarawa adalah pengantin laki-laki harus memegang atau menyent uh salah satu anggot a tubuh pengantin perempuan, biasanya yang dipegang buah dada pengantin perempuan sebagai simbol seperti gunung. Hal itu dimaksudkan agar kelak rezekinya menggunung seperti gunung dan menurut anggapan mereka di sinilah letak fungsi bagian tubuh yang terpenting, yaitu sumber makanan pertama kali jika manusia baru dilahirkan. Rabaan tidak selalu

${ }^{6}$ A. Racmah, Adat dan Upacara Perkawinan Daerah Sulawesi Selatan (Makassar: Pustaka Daerah Sulawesi Selatan, 2006), h. 28.

${ }^{7}$ Depertemen Pendidikan Nasional, Kamus Besar Bahasa Indonesia (Cet. III; Jakarta: PT Balai Pustaka, 2005), h. 1208

${ }^{8}$ A. Racmah, Adat dan Upacara Perkawinan Daerah Sulawesi Selatan, h. 42 


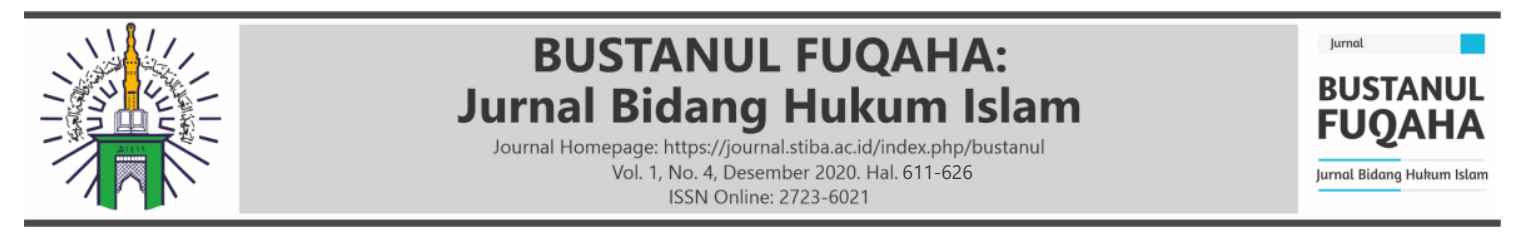

ditunjukkan pada buah dada saja, tetapi bergantung pada kepercayaan yang dianut; seperti ada yang pertama-tama meraba ubun-ubun atau leher bagian belakang maknanya supaya wanita itu tunduk sama suaminya ${ }^{9}$.

Perlu digaris-bawahi bahwa sebagian dari kaum muslimin terutama di daerah Bugis, bahwasanya mereka mewajibkan adanya ritual seperti ini, dengan alasan ketakutan akan terjadinya hal-hal yang tidak diinginkan, misalnya mempelai pria tidak disukai oleh istrinya, yang mana ujungnya akan terjadi perceraian. Untuk itu, dalam menghindari hal-hal yang tidak diinginkan, maka didatangkan Pappasikarawa. Pappasikarawa adalah orang yang dipilih dan diberikan kepercayaan untuk mempertemukan mempelai pria dan wanita dalam tempat yang telah disediakan ${ }^{10}$.

Tradisi Mappasikarawa seolah-olah telah menjadi sesuatu yang wajib diadakan bagi setiap orang yang akan melaksanakan perkawinan. Kegiatan tersebut dilakukan sebelum akad nikah yang mana dalam pandangan Islam kedua mempelai belum menjadi suami istri yang sah. Namun, masyarakat masih tetap meyakini adat istiadat yang di wariskan dari nenek moyang mereka. Sebagaimana contoh tradisi te'nea di daerah Gowa, awalnya bertujuan baik (silaturahim) dan mempererat kekerabatan, namun pada perjalananya bergeser pemaknaannya sehingga berimplikasi pada akidah seorang muslim ${ }^{11}$. Tentunya, hal seperti tradisi Mappasikarawa juga harus dikaji dan diteliti bagaimana pandangan syariat hukum Islam dalam hal tersebut, karena sesuatu yang bertentangan dengan syariat hukum Islam tentu tidak boleh dilakukan, dan masyarakat harus rela meninggalkannya meskipun adat tersebut telah diwariskan secara turun temurun dan telah mandarah daging. Terlebih lagi jika adat istiadat dijadikan sebagai sesuatu yang harus dikerjakan dan dijadikan sebagai suatu kepercayaan tertentu. Dalam kaidah fikih disebutkan:

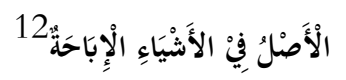

Artinya:

\section{"Hukum asal terhadap sesuatu adalah boleh".}

Segala sesuatu dalam muamalah itu asalnya boleh saja, selama tidak ada dalil yang melarangnya atau selama tidak bertentangan dengan syariat. Termasuk adat atau kebiasaan yang dilakukan secara turun-temurun, jika dalam kegiatan tersebut tidak ada yang bertentangan dengan syariat hukum Islam maka hal tersebut boleh saja dilakukan, namun, jika adat atau kebiasaan tersebut terdapat sesuatu yang bertentangan dengan

\footnotetext{
${ }^{9}$ A. Racmah, Adat dan Upacara Perkawinan Daerah Sulawesi Selatan, h. 103.

${ }^{10}$ A. Racmah, Adat dan Upacara Perkawinan Daerah Sulawesi Selatan, h. 104.

${ }^{11}$ Wijaya, H., \& Akbar, F. "Tradisi Te'nea dalam Perspektif Hukum Islam (Studi Kasus di Desa Majannang)", NUKHBATUL'ULUM: Jurnal Bidang Kajian Islam 6, no. 1 (2020); h. 145.

${ }^{12}$ Muḥammad Șidqī Ibn Aḥmad Ibn Muḥammad al-Burnī Abī al-Haris̉ al-Gazzī, al-Waj̃z Fi Iḍāḥi Qawā 'id al-Fiqh al-Kulliyyah (Cet. V; Beirut: Muassasah al-Risālah, 1422 H/2002 M), h. 191.
} 


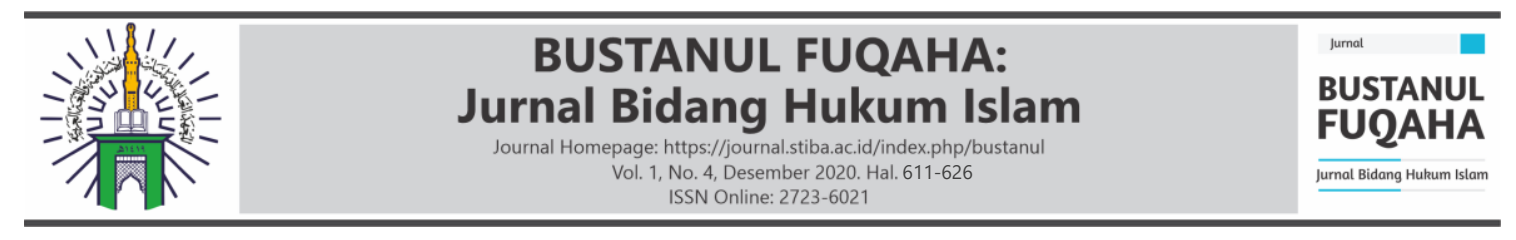

syariat hukum Islam, maka hal ini tidak boleh dilakukan dan harus dihentikan dan ditinggalkan. Pemaparan tersebut memberikan inspirasi kepada penulis untuk melakukan serangkaian penelitian yang kemudian dituangkan dalam karya tulis ilmiah, yang membahas tradisi Mappasikarawa setelah akad nikah pada masyarakat Bugis Desa Kaballangan Kecamatan Duampanua Kabupaten Pinrang Provinsi Sulawesi Selatan dalam perspektif hukum Islam.

Berdasarkan uraian di atas, maka yang akan dijadikan pokok permasalahan adalah: (1) Bagaimana tradisi Mappasikarawa pada perkawinan Bugis dalam perspektif hukum Islam?, dan dari pokok permasalahan tersebut dirumuskan beberapa sub masalah sebagai berikut: (2) Bagaimana tradisi perkawinan suku Bugis?; (3) Bagaimana pandangan hukum Islam terhadap tradisi Mappasikarawa di Desa Kaballangan Kecamatan Duampanua Kabupaten Pinrang?. Berdasarkan pada rumusan masalah tersebut pula, maka tujuan penelitian ini adalah: Pertama, untuk mengetahui dan memahami tradisi perkawinan suku Bugis secara lebih khusus berkenaan adat Mappasikarawa. Kedua, untuk memahami bagaimana pandangan hukum Islam terhadap tradisi Mappasikarawa di Desa Kaballangan Kecamatan Duampanua Kabupaten Pinrang.

Penelitian ini termasuk jenis penelitian lapangan (field research) kualitatif, yaitu peneliti melakukan penelitian langsung di lokasi untuk mendapatkan dan mengumpulkan data. Menurut Sukardi penelitian kualitatif adalah peneliti berusaha mengambarkan kegiatan penelitian yang dilakukan pada objek tertentu secara jelas dan sistematis, juga melakukan eksplorasi, menggambarkan, dengan tujuan untuk menerangkan dan memprediksi terhadap suatu gejala yang berlaku atas dasar data yang diperoleh di lapangan ${ }^{13}$. Pendekatan yang digunakan dalam penelitian ini adalah pendekatan normatif dan sosiologis. Pendekatan normatif yaitu suatu pendekatan yang memandang agama dari segi ajarannya yang pokok dan asli dari yang Maha Kuasa, yang di dalamnya belum terdapat penalaran pemikiran manusia ${ }^{14}$.

Pendekatan sosiologis yaitu pendekatan yang dilakukan dengan melihat dan mengamati gejala-gejala sosial yang terjadi dalam masyarakat kabupaten Pinrang terhadap tradisi Mappasikarawa dalam perkawinan suku Bugis Pinrang. Pendekatan sosiologis menjadikan suatu fenomena sosial dapat dianalisis dengan faktor-faktor yang mendorong terjadinya hubungan, mobilitas sosial serta keyakinan-keyakinan yang mendasari terjadinya proses tersebut ${ }^{15}$.

Studi tentang perkawinan merupakan salah satu dari permasalahan fikih. Pembahasan tentang ini dapat dilihat pada beberapa literat ur dan karya tulis, baik berupa artikel maupun buku, di antaranya:

\footnotetext{
${ }^{13}$ Sukardi Metodologi Penelitian Pendidikan Kompetensi dan Prakteknya (Cet: III; Jakarta: PT. Bumi Aksara, 2005M), h. 14.

${ }^{14}$ Abudin Nata, Metodologi Studi Islam (t. Cet. Jakarta: Raja Grafindo, 2008), h. 34.

${ }^{15}$ Abudin Nata, Metodologi Studi Islam (t. Cet. Jakarta: Rajawali Pers, 2013), h. 39.
} 


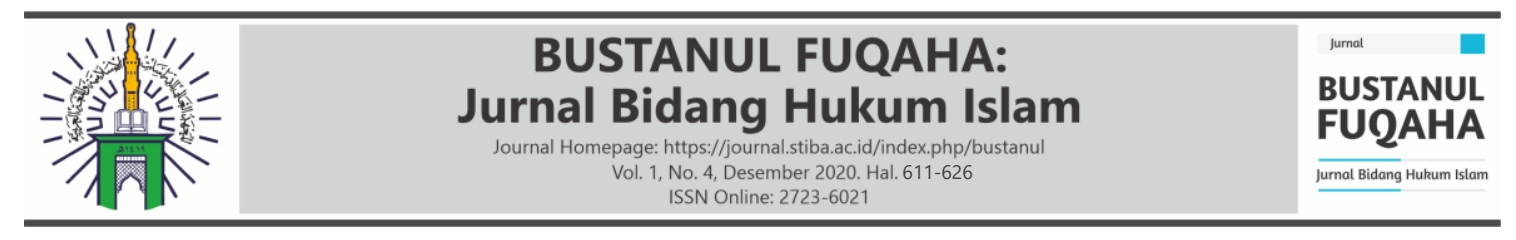

(1) Arini Safitri dalam karyanya yang berjudul, "Tradisi Mappasikarawa dalam Perkawinan Masyarakat Suku Bugis Kabupaten Kolaka”. Pembahasan inti dalam karyanya adalah untuk mengetahui bagaimana tahapan pelaksanaan tradisi perkawinan serta makna simbolik yang terdapat pada tradisi Mappasikarawa dalam perkawinan suku Bugis. Penelitian ini hanya membahas tentang tradisi Mappasikarawa dalam segi budaya, dan belum membahas tradisi Mappasikarawa dalam tinjauan hukum Islam ${ }^{16}$.

(2) Hardianti dalam karyanya yang berjudul, "Adat Perkawinan Bugis Bone Desa Tuju-Tuju Kecamatan Kajuara Kabupaten Bone dalam Perspektif Budaya Islam”. Pembahasan inti dalam karya ini adalah untuk mengetahui tahap-tahap dalam proses perkawinan adat Bugis Bone serta mengetahui makna dan pesan simbolik yang terkandung dalam proses upacara perkawinan pada suku Bugis. Penelitian ini hanya membahas tentang tradisi perkawinan dalam perspektif budaya Islam saja, dan belum membahas tentang perkawinan suku Bugis dalam perspektif hukum Islam $^{17}$.

Dari kedua kajian yang telah disebutkan di atas, belum ditemukan sebuah penelitian yang mengkaji adat Mappasikarawa suku Bugis dari sudut pandang hukum Islam.

\section{PEMBAHASAN}

\section{Profil Desa Kaballangan, Kabupaten Pinrang}

Nama Kaballangang yang kita kenal sekarang berasal dari sebuah sejarah (Barang Tompo) yaitu seekor kerbau jantan berwarna putih yang matanya juga putih. Dalam bahasa Bugis, mata putih disebut "Ballang Mata". Adapun pengaruh bahasa dan untuk memudahkan penyebutan yang disesuaikan dengan masyarakat setempat, maka sebutan tersebut lambat laun menjadi "Laballang" ${ }^{18}$. Dalam perkembangan selanjutnya, karena pengaruh informasi dan dialeg setempat, maka sebutan tersebut tadi menjadi "Kaballangang", yang secara etimologi mengandung makna khusus yaitu "Ballang Mata" yang dalam bahasa Indonesia berarti mata jernih yang diartikan sebagai penglihatan suci ${ }^{19}$.

Kaballangan adalah desa yang ada di wilayah pemerintahan Kecamatan Duampanua Kabupaten Pinrang yang berjarak kurang lebih $15 \mathrm{~km}$ ke arah selatan dari ibu kota Kecamatan Duampanua. Desa Kaballangang mempunyai luas wilayah kurang

\footnotetext{
${ }^{16}$ Arini Safitri, Wa Kuasa Baka, Sitti Hermina. Tradisi mapasikarawa dalam perkawinan masyarakat bugis di kecamatan wolo kabupaten kolaka, Jurnal Kelisanan Sastra dan Budaya Vol. 1, No 1 (2018): h. 56.

${ }^{17}$ Hardianti, Adat Perkawinan Bugis Bone Desa Tuju-Tuju Kecamatan Kajuara Kabupaten Bone dalam Perspektif Budaya Islam, Skripsi, (Makassar; UIN Alauddin, 2015), h. ix.

${ }^{18}$ Dokumen Rencana Pembangunan Jangka Menengah Desa Kaballangan 2016-2022, h. 4.

${ }^{19}$ Dokumen Rencana Pembangunan Jangka Menengah desa Kaballangan 2016-2022, h. 4.
} 


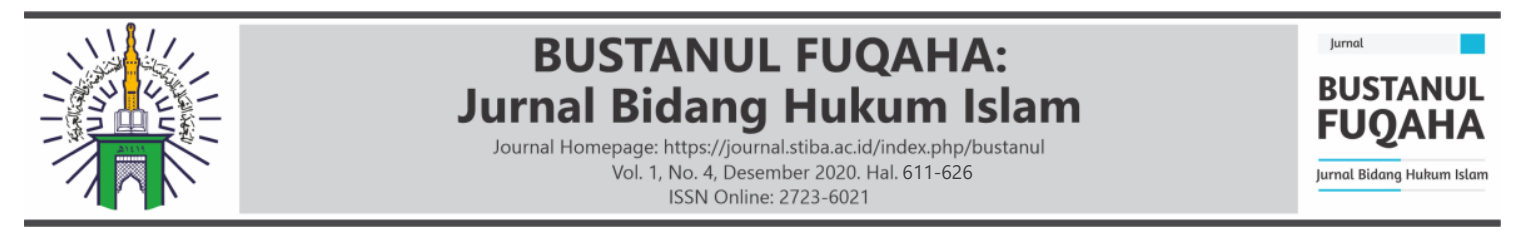

lebih $1.634 \mathrm{~km}^{220}$. Dari data yang diperoleh dari bulan Maret 2020 menunjukkan bahwa jumlah penduduk Desa Kaballngan sebanyak 2203 jiwa. Dengan rincian laki-laki sebanyak 1079 jiwa dan perempuan sebanyak 1124 jiwa dengan jumlah kepala keluarga sebanyak $602 \mathrm{KK}^{21}$. Sebagian besar penduduk Desa Kaballangan bermata pencaharian peternak ayam, itik dan sapi. Selain peternakan, sebagian masyarakat juga berprofesi sebagai petani, baik sawah maupun kebun. Selain itu, sebagian kecil lainnya sebagai buruh harian, pedagang serta sedikit yang berprofesi sebagai Pegawai Negeri Sipil (PNS).

Kabupaten Pinrang adalah daerah mayoritas Islam. Kabupaten ini penduduknya menganut 4 agama yaitu: Islam, Kristen, Hindu dan Budha. Meskipun begitu, toleransi beragama begitu kental dan kuat di kalangan masyarakat. Desa Kaballangan adalah salah satu dari beberapa desa yang masyarakatnya mayoritas adalah muslim, di mana dalam desa tersebut penduduknya lebih banyak memeluk agama Islam daripada agama Kristen. Desa Kaballangan pun memiliki tiga buah Masjid dan satu Gereja yang masih digunakan untuk melaksanakan ibadah. Masyarakat muslim di Desa Kaballangan dikenal sebagai pemeluk yang taat terhadap syariat agama dan rajin menjalankan ibadah. Walaupun begitu adat istiadat daerah setempat juga masih cukup kental dan masih eksis hingga hari dewasa ini.

\section{Tradisi Mappasikarawa pada Perkawinan Bugis Pinrang}

Setelah melakukan observasi dan pendekatan kepada seluruh komponen masyarakat Desa Kaballangan dengan mewawancarai pihak terkait, maka dapat ditemukan bahwa kegiatan Mappasikarawa memiliki beberapa proses dan tahapan khusus dalam melangsungkan perkawinan adalah sebagai berikut:

\section{Pertama, Kegiatan Mappasikarawa Dilakukan Sebelum Akad Nikah}

Bagi mayoritas masyarakat Kabupaten Pinrang, kegiatan Mappasikarawa adalah merupakan bagian yang tidak bisa dipisahkan dalam prosesi perkawinan. Kegiatan ini dilakukan sebelum akad nikah dengan tujuan agar pengantin tersebut mendapatkan kebahagiaan, kedamaian, kesejahteraan lahir dan batin dalam mengarungi bahtera kehidupan rumah tangga. Proses kegiatan Mappasikarawa ini diawali dengan mempelai laki-laki mendatangi mempelai wanita di dalam kamar yang telah disediakan. Dalam kunjungan tersebut biasanya pintu kamar tertutup rapat dan dijaga oleh orang-orang yang memiliki kekuasaan atau orang yang dihormati oleh pihak keluarga mempelai wanita.

${ }^{20}$ Papan Potensi Desa, Keadaan Geografi Desa Kaballangan Kecamatan Duampanua Kabupaten Pinrang, 2016.

${ }^{21}$ Papan Potensi Desa, Keadaan Geografi Desa Kaballangan Kecamatan Duampanua Kabupaten Pinrang, 2016. 


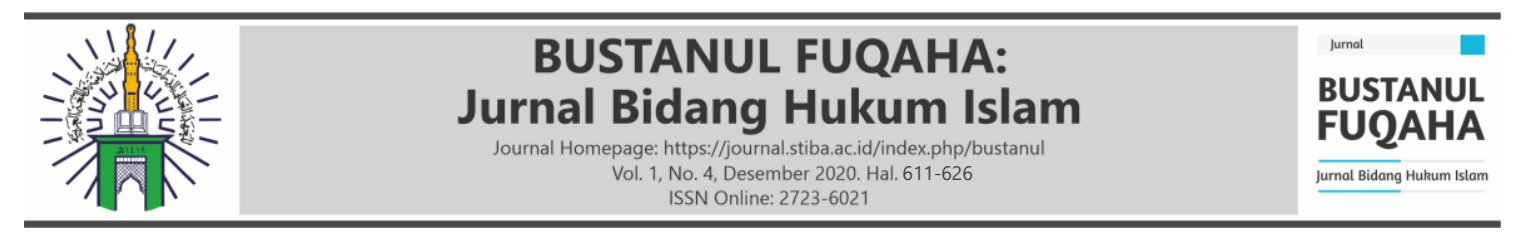

Pintu baru dapat dibuka jika pihak mempelai laki-laki telah menyerahkan "pembuka pintu" sebagai syarat agar keluarga wanita setuju untuk membuka kamar. Biasanya pihak mempelai laki-laki menyerahkan sejumlah materi (uang logam, permen dan semacamnya) yang dihamburkan di depan pintu kamar mempelai wanita. Jika pihak penjaga pintu masih tarik-menarik, dan belum berkenan membuka pintu, maka pihak mempelai laki-laki akan menambahkan sejumlah uang kertas agar para penjaga pintu berkenan membiarkannya masuk ke dalam kamar pengantin wanita. Adapun maksud dari aktivitas yang diistilahkan "Gaukeng" ini adalah agar sang suami kelak tidak mudah menguasai dan memperdaya istrinya karena diperoleh dengan susah payah.

Setelah mempelai laki-laki masuk ke dalam kamar selanjutnya mempelai lakilaki didudukkan di samping mempelai wanita untuk mengikuti prosesi Mappasikarawa. Adapun orang yang akan melakukan kegiatan Mappasikarawa adalah orang-orang panutan atau pilihan yang ilmunya lebih tinggi dan mempunyai pengalaman mampu menyatukan cinta kedua mempelai walaupun keduanya belum saling kenal. Adapun orang pilihan yang dimaksud disebut Pappasikarawa. Setelah kegiatan Mappasikarawa dianggap selesai dan mempelai laki-laki menerima mempelai wanita dan begitu pula sebaliknya, penghulu akan didatangkanlah untuk menikahkan kedua mempelai tersebut.

\section{Kedua, Bagian Tubuh yang Akan Disentuh Saat Prosesi Mappasikarawa}

Terdapat banyak versi tentang bagian anggota tubuh wanita paling baik untuk disentuh pertama kali oleh mempelai laki-laki tergantung pada niat Pappasikarawa. Jika niatnya jelek, maka akan mengarahkan tangan mempelai laki-laki ke bagian tubuh mempelai wanita yang dianggap tidak baik atau tabu untuk disentuh. Misalnya, mengarahkan tangan mempelai laki-laki ke bagian tengah leher paling bawah (edde), dan kepala dahi paling atas perbatasan kepala paling depan ( $b u w u)$. Menurut kepercayaan sebagian masyarakat bahwa bagian itu dilarang atau sedapat-dapatnya tidak disentuh karena dapat menyebabkan salah satu di antaranya berumur pendek apakah laki-laki atau perempuannya. Hal tersebut disebabkan karena kedua bagian anggota tubuh tersebut adalah berlubang sebagai simbol kuburan. Untuk itulah maka pihak kedua mempelai memilih orang-orang pintar yang benar-benar dapat dipercaya untuk melakukan kegiatan Mappasikarawa, sebab sangat menentukan hidup matinya dan keberlanjutan kehidupan rumah tangga pasangan suami istri yang akan menikah tersebut.

Menurut H. Malla ${ }^{22}$ salah seorang tetua untuk prosesi Mappasikarawa di desa Kaballangan Kecamatan Duampanua Kabupaten Pinrang menjelaskan tata cara Mappasikarawa sebagai berikut: Pertama, Ibu jari (jempol) tangan laki-laki dan perempuan dipertemukan (berhadapan); Kedua, Pappasikarawamemegang kedua ibu jari tersebut; Ketiga, Pappasikarawa memerintahkan kepada laki-laki untuk memasukkan sedikit kuku ibu jarinya pada sela kuku ibu jari perempuan (sekitar 3 detik); Keempat,

\footnotetext{
${ }^{22}$ Malla (81 Tahun), tokoh Mappasikara (wawancara, 26 Maret 2020)
} 


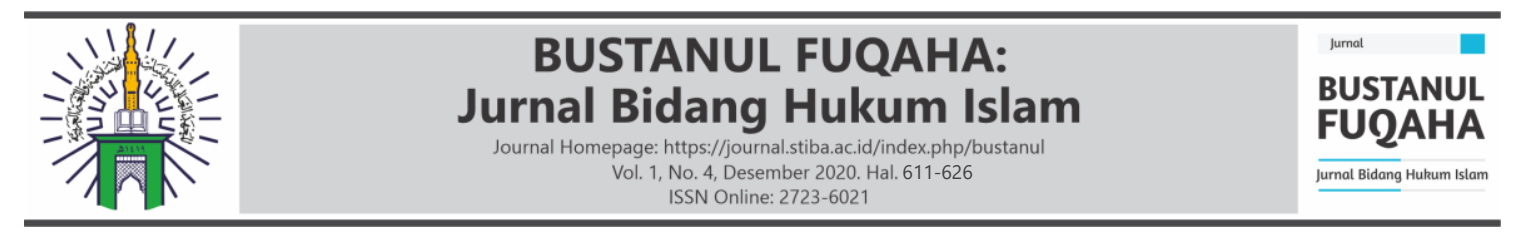

Pappasikarawa memerintahkan kepada pengantin wanita untuk melakukan hal yang sama kepada calon suaminya dengan waktu 3 detik; Kelima, Pappasikarawa membawa tangan pengantin pria memegang pangkal lengan pengantin perempuan (pangkal lengan yang berisi) kemudian Pappasikarawa menyuruh pengantin pria untuk berdoa dalam hati semoga mendapatkan kemurahan rezki, kebahagiaan dan keturunan yang baik sekitar 3 menit; Keenam, Pappasikarawa menyerahkan kembali pengantin pria dan wanita kepada indo' botting untuk acara selanjutnya.

Menurut Abdullah ${ }^{23}$ salah seorang tokoh masyarakat yang memahami dan pelaku acara Mappasikarawa di Kecamatan Duampanua Kabupaten Pinrang mengemukakan bahwa dalam prosesi acara Mappasikarawa diawali oleh mempelai laki-laki menyentuh bagian tubuh yang baik mempelai wanita yang disesuaikan dengan peruntukannya. Misalnya, jika mempelai wanita dikawinkan paksa alias bukan kemauannya melainkan hanya kemauan orang tuanya, dan ada kemungkinan setelah menikah nantinya akan meninggalkan sang suami karena tidak suka, maka menurutnya bagian tubuh yang paling baik untuk disentuh mempelai laki-laki adalah bawah daun telinga atau hidung mempelai perempuan yang diistilahkan "riteddoi" artinya ditundukkan. Ia mengatakan analoginya sama seperti kerbau, jika diteddo (dicucuk) hidungnya, maka apapun yang dilakukan padanya akan tetap tunduk dan mengikuti segala perlakuan tuannya. Jika kedua pasangan suami istri tersebut kelak diharapkan murah rezkinya dan tidak pernah merasakan kesulitan rezki maka diaanjurkan untuk menyentuh pangkal lengan atas.

Menurut Syamsuddin Malla ${ }^{24}$ sebagai Pappasikarawa di Kelurahan Pekka Bata Kecamatan Duampanua menyatahkan bahwa ketika mempelai laki-laki dan perempuan sudah berhadapan di dalam kamar pengantin, maka pertama-tama yang harus dilakukan Pappasikarawa adalah mengambil ibu jari jempol tangan laki-laki dan perempuan dipertemukan bersentuhan, kemudian Pappasikarawa memerintahkan kepada pengantin laki-laki dan pengantin perempuan untuk melemaskan ibu jarinya masing-masing (tidak saling menekan), kemudian Pappasikarawa memegang kedua ibu jari pengantin dengan tangan kiri sedangkan ibu jari tangan kanan Pappasikarawa menyentuh langit-langit di mulutnya guna mengambil sedikit (air kalkautzar) sambil Pappasikarawa membaca bacaan yang telah dipelajari sebelumnya. Jika masih ada salah satu pihak bersikukuh menekan ibu jari lawannya (baik mempelai laki-laki maupun mempelai perempuan), maka nama Pappasikarawa tetap menunggu hingga masing-masing mengalah. Biasanya dalam proses ini, kadang-kadang ada salah satu pihak yang berusaha mengalahkan lawannya, karena menurut kepercayaan sebagian masyarakat jika pada saat ibu jari dipertemukan lalu ada salah satu pihak yang berhasil mengalahkan lawannya, maka kelak dia pun mengusainya. Misalnya, mempelai perempuan mengalahkan laki-laki maka kelak dalam perjalanan kehidupan rumah tangganya, istri akan menguasai suami

\footnotetext{
${ }^{23}$ Abdullah (73 Tahun), tokoh Masyarakat (wanwancara, 28 Maret 2020)

${ }^{24}$ Syamsuddin Malla (53 Tahun), pelaksana Pappasikara( Wawancara, 2 April 2020).
} 


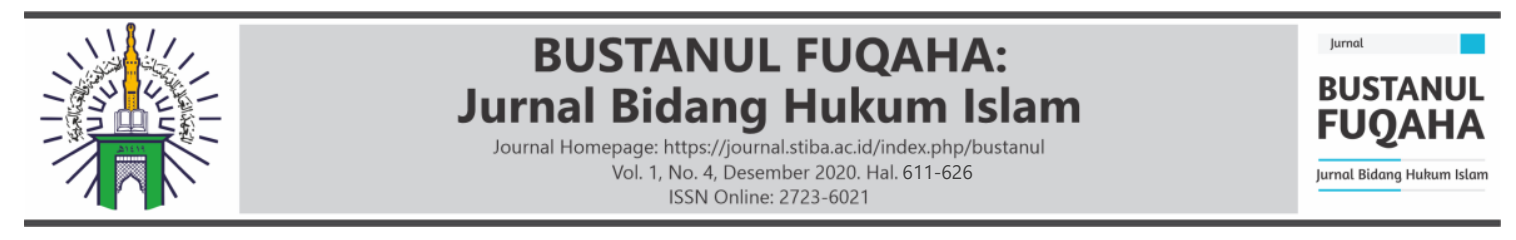

demikian pula sebaliknya. Kemudian Pappasikarawa membawa ibu jari pengantin pria menuju ke arah payudara mempelai wanita (lappo susu) sebelah kiri pengantin wanita. Setelah semuanya selesai Pappasikarawa menyerahkan kembali kedua mempelai kepada indo' botting untuk acara selanjutnya.

Dengan demikian, dapat disimpulkan bahwa dari ke tiga Pappasikarawa tersebut, meskipun berbeda-beda tata cara pelaksanaan Mappasikarawa-nya, namun dalam keyakinan masyarakat, maksud dan tujuannya sama yaitu agar kedua mempelai mendapatkan kebahagiaan, kedamaian dan kesejahteraan hidup dalam mengarungi bahtera rumah tangga.

\section{Ketiga, Doa yang Dibacakan oleh Pappasikarawa Kepada Kedua Mempelai}

Adapun doa yang dibacakan oleh Pappasikarawa kepada kedua mempelai adalah sebagai berikut:

1. Doa yang dibacakan oleh Abdullah sebagai Pappasikarawa adalah

"Arusu abiona neneta Adam rieddu naripattekka maniangsalo nariala

katoang ribu lena rakkeangnge nariunung katoang siwenni, purana

riurung naritappani nancajina neneta hawa, naribaratemmuina akki

neneta Adam akki siwennie'?25.

Kata-kata siwenni artinya satu malam dapat diganti dengan kata duampenni (dua malam), tellumpenni (tiga malam) tergantung berapa malam kedua mempelai diharapkan akur (sipoji) dan konsekuensi dari keadaan itu akan terjadi hubungan suami istri. Berdasarkan pengalaman nama orang terhadap beberapa pasangan pengantin yang telah dipercaya kepadanya untuk ripasikarawa menunjukkan bahwa berkat bacaan tersebut telah menyebabkan pasangan pengantin baru tidak bertahan lama-lama atau tidak menunggu dua sampai tiga malam baru menikmati malam pertamanya, melainkan kadang-kadang tamu masih berkumpul dan belum beranjak dari rumah hajatan, namun pengantin wanita kadang-kadang sudah tidak sabaran menantikan suaminya masuk ke kamar pengantin.

2. Pada saat H. Malla sebagai Pappasikarawa memegang kedua ibu jari kedua mempelai dengan tangan kirinya sedangkan ibu jari tangan kanan Pappasikarawa menyentuh langit-langit di mulutnya sambil Pappasikarawa membaca: Allah Ta'ala makkarawa, Fatimah ri karawa, Muhammad mappanedding, barakka lailaha illallah. Bacaan ini hanya di baca dalam hati Pappasikarawa ${ }^{26}$.

3. Pada saat $\mathrm{Hj}$. Hania ${ }^{27}$ sebagai Pappasikarawa meminta kepada laki-laki untuk memasukkan sedikit kuku ibu jarinya pada selah kuku ibu jari permpuan selama 3 detik dengan membaca: "Faraouhum waraehaanum wa jannatun naim nasrhun minallah.

\footnotetext{
${ }^{25}$ Abdullah (73 Tahun), tokoh masyarakat (Wanwancara, 28 Maret 2020).

${ }^{26}$ Malla (81 Tahun), tokoh Mappasikara (wawancara, 26 Maret 2020).

${ }^{27}$ Hania (72 Tahun) Pelaku Pappasikarawa (Wawancara, 5 April 2020).
} 


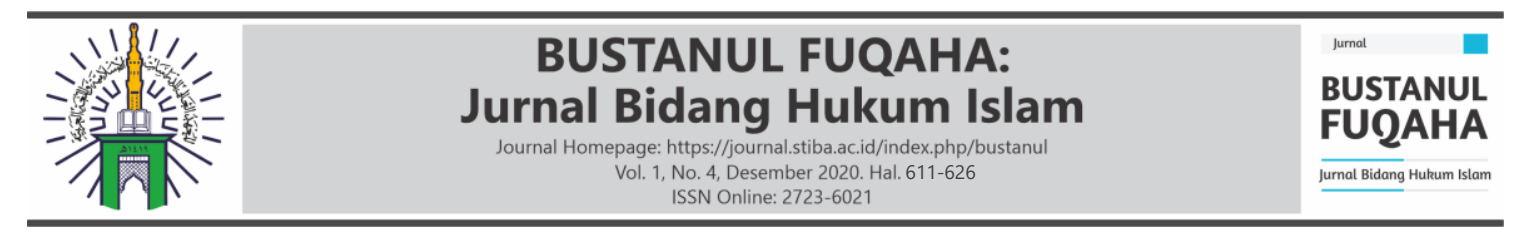

4. Pada saat Syamsuddin Malla sebagai (Pappasikarawa) mengambil ibu jari pengantin pria kemudian diletakkan disamping kiri kening (dekat telinga kiri) lalu kemudian Pappasikarawa membaca ayat Al-Qur'an “Qul in kuntum tuhibbunallah", kemudian Pappasikarawa memerintahkan kepada pengantin pria untuk melanjutkan ayat tersebut dengan membaca "Fattabiuni yuhbib kumullah"28. Tujuan dari bacaan ini adalah agar pengantin tersebut saling mencintai, mengasihi, menyayangi serta mendapatkan kebahagiaan, kedamaian, dan kesejahteraan lahir batin dalam mengarungi batera kehidupan rumah tangga.

\section{Tinjauan Hukum Islam terhadap Tradisi Mappasikarawa}

Dalam hasil penelitian yang diperoleh melalui wawancara mengenai tata cara serta bacaan doa yang dilakukan oleh masyarakat ketika melaksanakan tradisi Mappasikarawa, dalam perkawinan suku Bugis Pinrang, maka dapat diuraikan pandangan hukum Islam tentang hal tersebut tidak boleh dan haram hukumnya untuk dilakukan kegiatan tersebut karena tidak sesuai dengan apa yang diajarkan oleh Nabi Muhammad saw. Dengan alasan sebagai berikut: Pertama, Kegiatan Mappasikarawa dilakukan sebelum akad nikah, sedangkan dalam hukum Islam laki-laki tidak boleh menyelami dan menyentuh perempuan yang bukan mahramnya. Dari Ma'kil bin Yasar ra. bahwa Nabi saw. pernah bersabda:

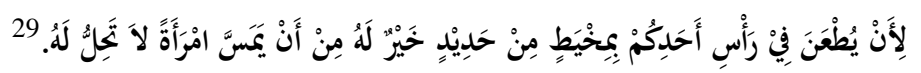

Artinya:

"Sekiranya kepala salah seorang di antara kalian ditusuk dengan jarum dari besi adalah lebih baik baginya dari pada dia menyentuh wanita yang tidak halal baginya".

Hadis ini dengan jelas menunjukkan penegasan akan haramnya seorang laki-laki menyentuh perempuan yang belum sepenuhnya sah sebagai mahramnya, demikian juga sebaliknya seorang perempuan tidak boleh menyentuh laki-laki yang bukan mahramnya. Walaupun sekedar sentuhan terhadap lawan jenis yang tidak dihalalkan oleh ajaran Islam maka hal tersebut tidak dibenarkan. Pada hadis ini juga terdapat ancaman yang keras (tegas) kepada pria yang menyentuh wanita ajnabi (yang bukan mahram) ${ }^{30}$. Padanya juga terdapat dalil at as haramnya bersalaman dengan wanita. Oleh karena itu, tidak diragukan bahwa bersalaman itu mengandung unsur bersentuhan. Dewasa ini, umat Islam banyak diuji dengan situasi ini, dan di antara mereka adalah dari kalangan ahli ilmu. Sekiranya mereka mengingkari perkara tersebut dengan hati mereka, tentu ada sedikit kemudahan

\footnotetext{
${ }^{28}$ Syamsuddin Malla (53 Tahun), pelaksana Pappasikara (Wawancara, 2 April 2020). M), h. 487.

${ }^{29}$ Ṭārik Ibn Abdillāh, al Mu'jam al-Kabīr Al-T abrān̄̄, (Cet. I; Riyaḍ: Dār al-Rāyah ,1414 H/1993

${ }^{30}$ Abū Mālik Kamāl Ibn Sayyid Sālim, Șạịh Fiqh al-Sunnah, Juz 3 (Cet I; Al-Qāhirah: Maktabah al-Taufĩqiyah, 2003), h. 190.
} 


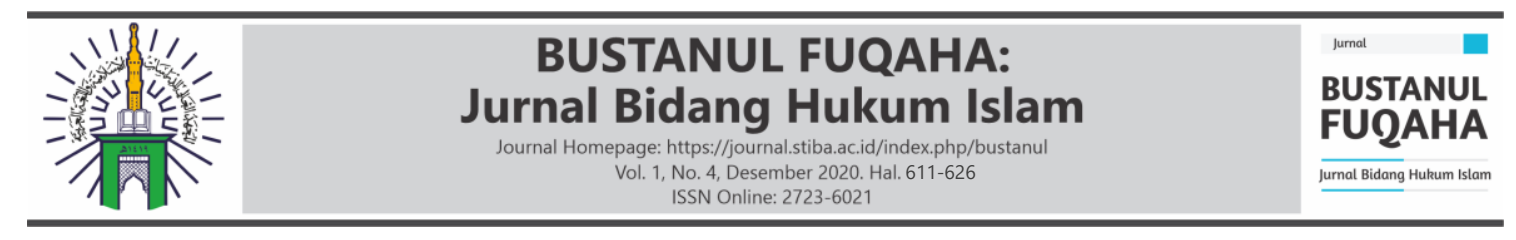

untuk menasehati mereka. Tetapi sayangnya, mereka menghalalkan perkara tersebut dengan berbagai cara (jalan) dan takwil (penafsiran).

Kedua, kegiatan Mappasikarawa yang dilakukan oleh laki-laki dan perempuan yang akan menikah dengan menyentuh bagian tubuh tertentu sesuai dengan instruksi Pappasikarawa merupakan kegiatan yang tidak ada contohnya dari Nabi Muhammad saw. dan beliau saw. tidak pernah menyentuh wanita dalam proses baiat. Diriwayatkan oleh Aisyah ra. bahwa Rasulullah saw. mengatakan kepada wanita yang dibaiatnya.

$$
31 \text { قَدْ بَيَعْتُكِكِ عَلَى ذَلِكَ }
$$

Artinya:

\section{"Aku membaiatmu dengan ini (ucapan)"}

Aisyah ra. berkata demi Allah tangan Nabi saw. sama sekali tidak menyentuh tangan wanita dalam prosesi baiat. Beliau tidak membaiat mereka melainkan dengan sabda beliau "Aku membaiatmu dengan ini (ucapan)"32.

Adapun dalam syariat Islam, kegiatan tersebut tidak dibenarkan karena mereka meyakini bahwa dengan melakukan kegiatan tersebut maka kedua mempelai akan mendapatkan kebahagiaan, kedamaian dan kesejahteraan hidup dalam mengarungi bahtera rumah tangga. Hal ini merupakan sebuah tradisi turun temurun dari nenek moyang mereka. Jika ditinjau dari sudut pandang Islam, Al-Qur'an sebagai pedoman hidup telah menjelaskan bagaimana kedudukan tradisi (adat istiadat) dalam agama itu sendiri. Oleh karena itu, nilai-nilai yang termaktub dalam sebuah tradisi dipercaya dapat mengantarkan keberuntungan, kesuksesan, kelimpahan, dan keberhasilan bagi masyarakat tersebut. Selanjutnya, setiap aturan-aturan, anjuran, perintah tentu saja akan memberi dampak positif dan setiap larangan yang diindahkan membawa keberuntungan bagi hidup manusia. Salah satu larangan yang akan membawa kemaslahatan bagi manusia adalah menjauhkan diri dari kebiasaan-kebiasaan nenek moyang terdahulu yang bertentangan ajaran Islam. Sebagaimana firman Allah Ta'ala dalam Qs. Al-Baqarah/2: 170 ,

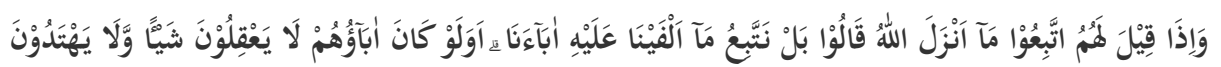

Terjemahnya:

"Dan apabila dikatakan kepada mereka, "Ikutilah apa yang diturunkan Allah," mereka menjawab, "(Tidak!) kami mengikuti apa yang kami dapati pada nenek

\footnotetext{
${ }^{31}$ Abī Muḥammad Maḥmūd Ibn Aḥmad al-Alnī, Umdatul Qorī Syarhi Șahị̣̄ al-Bukhārī, Juz 5 (Cet I; Beirut: Dār Al-Fikh, 2016), h.197.

${ }^{32}$ Abū Mālik Kamāl Ibn Sayyid Sālim, Șạ̄ị Fiqh al-Sunnah, h. 191.
} 


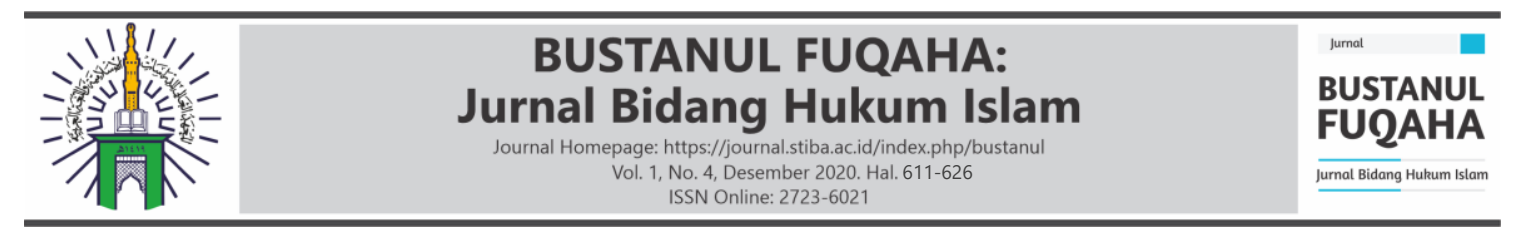

moyang kami (melakukannya). Padahal nenek moyang mereka itu tidak mengetahui apa pun dan tidak mendapat petunjuk"33.

Ketiga, doa yang dibacakan oleh Pappasikarawa mengandung unsur kesyirikan dengan mempercayai dan meyakini bahwasanya doa tersebut akan mendapatkan keberkahan dalam perkawinan kedua mempelai, sehingga ketika doa tersebut dibacakan maka kedua mempelai akan saling mencintai, mengasihi, menyayangi serta mendapatkan kebahagiaan, kedamaian, dan kesejahteraan lahir batin dalam mengarungi batera kehidupan rumah tangga. Adapun apabila doa tersebut tidak dibacakan, maka hubungan kedua mempelai tidak akan harmonis sehingga rumah tangganya akan berantakan dan ujung-ujungnya adalah sampai ke tahap perceraian. Hal ini merupakan suatu perbuatan yang bertentangan dengan syariat Islam dengan mempercayai dan meyakini bahwasanya kebahagiaan kedua mempelai tergantung pada doa Pappasikarawa yang mendoakan kedua mempelai pada saat kegiatan Mappasikarawa dilakukan.

Rasulullah saw. memerintahkan kepada pasangan suami istri untuk merenungkan tujuan perkawinan, merasakan karunia yang Allah swt. berikan kepada keduanya agar keduanya dapat menjalani malam ini dengan baik, semakin mempererat hubungan di antara keduanya pada malam pengantin dan malam-malam berikutnya ${ }^{34}$. Rasulullah saw. bersabda apabila seorang dari kalian menikahi seorang wanita atau budak, maka hendaklah membaca doa:

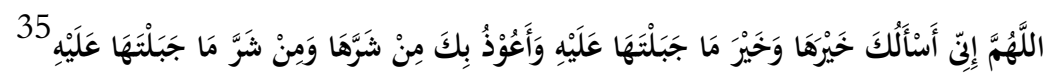

Artinya:

"Ya Allah, sesungguhnya aku memohon kepadamu kebaikannya dan kebaikan yang engkau ciptakan pada wataknya, dan aku berlindung kepadamu dari keburukannya dan keburukan yang engkau ciptakan pada wataknya”.

Inilah doa yang diajarkan oleh Rasulullah saw. kepada pasangan suami istri yang telah menikah. Adapun doa ini dibaca pada saat mempelai laki-laki memasuki kamar mempelai wanita sambil memegang ubun-ubun istrinya seraya membaca doa tersebut. Rasulullah saw. juga menganjurkan membaca doa keselamatan atas perkawinan kedua mempelai pada saat berjabat tangan dengan mempelai pria dengan membaca:

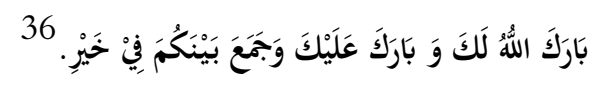

Artinya:

${ }^{33}$ Kementrian Agama Republik Indonesia, Alquran al-Karim dan Terjemahnya, (Cet II; Yogyakarta: Ma'had al-Nabawī, 2011 M), h. 26.

${ }^{34}$ Ahmad Muhammad Abdurrahim, Aku Terima Nikahnya (Cet. III; Jakarta Timur: Istanbul, 2018), h. 74 .

${ }^{35}$ Abū Bakar Jabir al-Jazāiri, Minḥāj al-Muslim (Cet. I; Damaskus: Maktabah al-Ulūm Wa alHikam, 2008), h. 694.

${ }^{36}$ Abū Bakar Jabir al-Jazāiri, Minḥāj al-Muslim, h.694. 


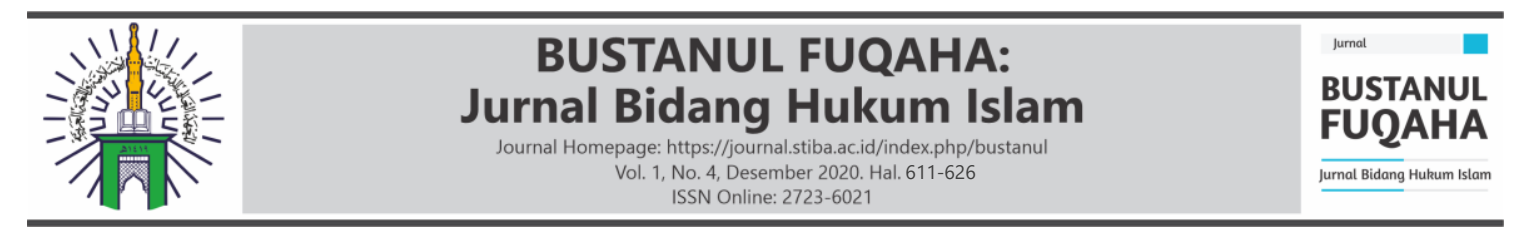

"Semoga Allah swt. memberi berkah untukmu. Semoga Allah menurunkan kebahagiaan atasmu.. Semoga Allah menyatukan kamu berdua dalam kebaikan”.

\section{KESIMPULAN}

Berdasarkan pembahasan yang telah diuraikan di atas, maka tradisi Mappasikarawa pada perkawinan suku Bugis Pinrang adalah merupakan salah satu kegiatan yang dilakukan sebelum akad nikah dengan tujuan agar pengantin tersebut mendapatkan kebahagiaan, kedamaian, kesejahteraan, lahir dan batin dalam mengarungi batera kehidupan rumah tangga. Proses kegiatan Mappasikarawa ini diawali dengan mempelai laki-laki mendatangi mempelai wanita di dalam kamar yang telah disediakan. Kegiatan ini telah mengakar dalam kegiatan perkawinan masyarakat Bugis Pinrang sehingga tiada perkawinan yang luput dari kegiatan Mappasikarawa tersebut.

Dalam tinjauan hukum Islam, tradisi Mappasikarawa memiliki cacat pelaksaaan mulai dari proses hingga bacaan saat pelaksanaan. Oleh karena itu, tradisi ini tidak boleh dan haram hukumnya untuk dilakukan. Kegiatan Mappasikarawa ini dilakukan sebelum akad nikah sedangkan dalam hukum Islam laki-laki tidak boleh menyalami dan atau menyentuh perempuan yang bukan mahramnya.

\section{DAFTAR PUSTAKA}

Abdurrahim, Ahmad Muhammad. (2018). Aku Terima Nikahnya. Cet. III; Jakarta Timur: Istanbul.

Al-Alnī, Abī Muḥammad Mạ̣mūd Ibn Aḥmad. (2016). Umdatul Qon̄ Syarhi Ṣạị̣̄ alBukhārī, Juz 5. Cet I; Beirut: Dār Al-Fikh.

Al-Gazzī, Muḥammad Șidqī Ibn Aḥmad Ibn Muḥammad al-Burn̄̄ Abī al-Ḥaris̀. (2002). al-Waj̄z Fi Iḍ̂hḥi Qawā ’id al-Fiqh al-Kulliyyah. Cet. V; Beirut: Muassasah alRisālah.

Al-Jazāiri, Abū Bakar Jabir. (2008). Minḥāj al-Muslim. Cet. I; Damaskus: Maktabah alUlūm Wa al-Hikam.

Depertemen Pendidikan Nasional. (2005). Kamus Besar Bahasa Indonesia. Cet. III; Jakarta: PT Balai Pustaka.

Dokumen Rencana Pembangunan Jangka Menengah Desa Kaballangan 2016-2022.

Hardianti. (2015). Adat Perkawinan Bugis Bone Desa Tuju-Tuju Kecamatan Kajuara Kabupaten Bone dalam Perspektif Budaya Islam, Skripsi, Makassar; UIN Alauddin.

Ibn Abdillah, Thorik. (1993). al Mu’jam al-Kabīr Ath-Thabrani. Cet. I; Riyad: Dar alRoyah.

Kementrian Agama Republik Indonesia. (2011). Alquran al-Karim dan Terjemahnya. Cet II; Yogyakarta: Ma'had al-Nabawi.

Nasution, Khairuddin. (2010). Pengantar Studi Islam. Jogjakarta: Academica. 


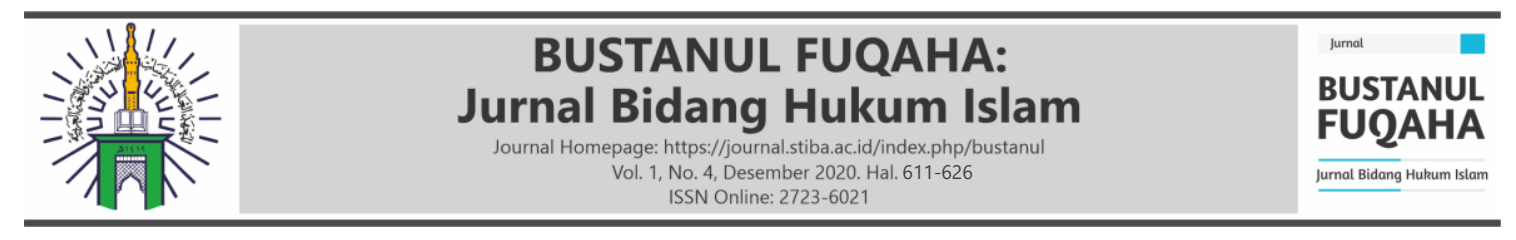

Nata, Abudin. (2008). Metodologi Studi Islam. Jakarta: Raja Grafindo. (2013). Metodologi Studi Islam. Jakarta: Rajawali Pers.

Papan Potensi Desa. (2016). Keadaan Geografi Desa Kaballangan Kecamatan Duampanua Kabupaten Pinrang.

Racmah, A. (2006). Adat dan Upacara Perkawinan Daerah Sulawesi Selatan. Makassar: Pustaka Daerah Sulawesi Selatan.

Rahman, R. A. (2016). Konsep Keadilan dalam Alquran. NUKHBATUL'ULUM: Jurnal Bidang Kajian Islam, 2(1), 167-175.

Safitri, A., Baka, W. K., \& Hermina, S. (2018). Tradisi Mapasikarawa Dalam Perkawinan Masyarakat Bugis di Kecamatan Wolo Kabupaten Kolaka. LISANI: Jurnal Kelisanan, Sastra, dan Budaya, 1(1), 56-64.

Sālim, Abū Mālik Kamāl Ibn Sayyid. (2003). Șahịh Fiqh al-Sunnah, Juz 1. Cet I; Kohiroh-Mișr: Maktabah al-Taufīkiyah.

Sukardi. (2005). Metodologi Penelitian Pendidikan Kompetensi dan Prakteknya. Cet: III; Jakarta: PT. Bumi Aksara.

Surakhmad, Winarno. (2004). Pengantar Penelitian Ilmiah. t. Cet. Bandung: Tarsito.

Usman, M. H., \& Aswar, A. (2020). KORELASI KEHIDUPAN BERISLAM MASYARAKAT DESA BARUGA DENGAN KEMAKMURAN, KEAMANAN DAN KETENTRAMAN HIDUP. Al-Din: Jurnal Dakwah dan Sosial Keagamaan, 6(1).

Wijaya, H., \& Akbar, F. (2020). Tradisi Te'nea dalam Perspektif Hukum Islam (Studi Kasus di Desa Majannang). NUKHBATUL'ULUM: Jurnal Bidang Kajian Islam, 6(1), 145-158.

\section{Sumber Wawancara}

Abdullah (73 Tahun), tokoh Masyarakat (Wanwancara, 28 Maret 2020).

Hania (72 Tahun) pelaku Pappasikarawa (Wawancara, 5 April 2020).

Malla (81 Tahun), tokoh Mappasikarawa (Wawancara, 26 Maret 2020).

Syamsuddin Malla (53 Tahun), pelaksana Mappasikarawa (Wawancara, 2 April 2020). 